\section{Inquiry into misconduct excoriates Michigan State}

Four years of acrimony at Michigan State University (MSU) have culminated in the finding that a graduate student was guilty of scientific misconduct for keeping research data to herself and publishing without the consent of the supervisor. Although an independent inquiry into the affair recommends that the student should be expelled, the chief casualty is likely to be the reputation of the university administration, which is accused of bias, inordinate delay in answering letters, buck-passing, a lack of understanding of the traditions of biomedical science and a failure to meet its responsibilities to the academic community. The inquiry recommends a review "to determine whether corrective actions are necessary".

The inquiry, whose report has not yet been published, was masterminded by Barbara Mishkin, a Washington lawyer specializing in misconduct. It was convened last March and submitted its report to the university on 14 December. The university has received comments from the principals and is expected to render a decision within a month. Its actions will be reviewed by the National Institutes of Health $(\mathrm{NIH})$, which funded the research.

The trouble dates back to 1987, when Maie ElKassaby became a PhD student in the pathology department of the veterinary school and started work with Jeffrey Williams of the microbiology department, holder of an NIH grant to study parasitic worm diseases in collaboration with a group of researchers and physicians in the Sudan.
By the summer of 1989 , Williams and his student had fallen out.

ElKassaby's membership in the PhD programme was terminated on two occasions, but by the end of 1989 the administration arranged that she should work for a master's degree under a new guidance committee. (She was reinstated to the $\mathrm{PhD}$ programme in December 1990.)

With the help of the academic committee, ElKassaby then prepared a manuscript for publication, but her offers of co-authorship to scientists at the Upjohn Company (who had developed her radioimmunoassay technique) and to physicians in the Sudan were declined because they had not seen the data on which the manuscript was based.

The inquiry says that these objections were "rejected or ignored" by the university administration and the guidance committee, one of whose members wrote a covering letter for the manuscript submitted to the Tropical Medicine and Parasitology. Ironically, the manuscript was accepted without review because of a "clerical error".

The inquiry finds that ElKassaby was guilty of scientific misconduct for having withheld data from her collaborators. Of ElKassaby's publication, the inquiry says that to have published work "inseparable from that of others" without their agreement or acknowledgement also constitutes "scientific misconduct", but that "her guilt is mitigated" by the connivance of her guidance committee and of MSU's vice president for research, John Cantlon.

\section{Meetings on British science}

NATURE is organizing two one-day public meetings to discuss proposals for the forthcoming white paper on the organization of British science, in Edinburgh and London.

On Friday 19 February, there will be a meeting in Edinburgh, jointly sponsored by the Edinburgh International Science Festival. The speakers will be Professor John Glover (University of Dundee), Sir Graham Hills, Professor J Maxwell Irvine (University of Aberdeen) and Professor David Wallace (University of Edinburgh). The meeting will be at the Queen Mother Conference Centre, Royal College of Physicians, 9 Queen Street, Edinburgh, and will start at 9.30 a.m.

Admission will be by ticket, free of charge, obtainable from Bruce Durie, Edinburgh International Science Festival, 1 Broughton Market, Edinburgh EN3 6NU. Coffee and tea will be provided. There will also be a sandwich lunch for those who want it, at a cost of $£ 5$ : please send a cheque, made out to the Edinburgh International Science Festival, with your ticket application.

On Friday 19 March, there will be a meeting at 9:30 a.m. in London at the Royal Society, 6 Carlton House Terrace, SW1. The speakers will include Sir Eric Ash (Rector, Imperial College London), Professor Michael Brady (University of Oxford) and Sir Mark Richmond (Chairman, Science and Engineering Research Council).

Admission will be by ticket, free of charge, obtainable from Mary Sheehan, Nature, 4 Little Essex Street, London WC2R 3LF. Coffee and tea will be provided. There will also be a sandwich lunch for those who want it, at a cost of $£ 5$ : please send a cheque, made out to Nature, with your ticket application.
The inquiry also exonerates Williams from ElKassaby's counter-charges that he sought to use her work for private gain, and that his termination of her research assistantship was improper. On the other hand, the inquiry accepts ElKassaby's view that Williams should not have disclosed her identity, but attributes that to the "collective inaction of the MSU administration".

The inquiry concluded that the university administration acted from fear that ElKassaby had been wrongly dismissed and that she might win a legal action, as well as by the suspicion that Williams was persecuting her. It complains that the administration should have "paid as much attention to faculty rights as to the rights of the student".

The charge that the administration made light of its "responsibilities to the academic community" is illustrated by its willingness to contemplate awarding ElKassaby a PhD "when her contribution to the research in question was minimal". MSU is also accused of having violated US federal regulations in carrying out its internal investigation of the dispute (which exonerated the academic guidance committee's members).

Apart from the recommendation that ElKassaby's PhD programme should be terminated and that she should be expelled, the inquiry says that MSU should develop policies for resolving conflicts between its departments and colleges, and for handling allegations of scientific misconduct. The final recommendation is that its report should be published.

John Maddox

\section{Montagnier and Mayor create AIDS foundation}

Paris. Luc Montagnier of the Pasteur Institute and Federico Mayor, director general of UNESCO, have co-founded a private organization to fund non-mainstream AIDS research and to support AIDS-related educational and social projects in Africa. But it is not yet clear whether this "World Foundation for Research and Prevention of AIDS", unveiled on 28 January in Paris, will have sufficient resources or clout.

Montagnier hopes for international participation, although the only declared donation so far is US\$500,000 from an Italian bank. UNESCO itself is not directly involved in the venture. One of the first areas to be targeted is Montagnier's own research on mycoplasmas, leaving him open to charges of conflict of interest in his role as final arbiter of scientific activities.

The foundation expects to establish applied clinical research centres in Europe and Africa for those who are seropositive. The foundation also plans to establish prevention and social programmes in Africa; the first would provide FF5 million (US\$1 million) to educate orphans whose parents have died of AIDS.

Declan Butler 